\title{
Assessment of Housing Attributes Towards Neighbourhood Satisfaction in The Klang Valley
}

\author{
Siti Nurul Munawwarah bt Roslan ${ }^{1}$, Wan Nor Azriyati bt Wan Abd Aziz ${ }^{2}$, Fatimah bt \\ Kari $^{3}$ and Nurulhuda bt Mohd Satar ${ }^{4}$ \\ ${ }^{1}$ Department of Economics, Faculty of Economics and Administration, University of Malaya / Department of \\ Business Management \& Law, Management \& Science University \\ ${ }^{2}$ Department of Estate Management, Faculty of Built Environment, University of Malaya. \\ ${ }^{3}$ Department of Economics, Faculty of Economics and Administration, University of Malaya. \\ ${ }^{4}$ Department of Economics, Faculty of Economics and Administration,University of Malaya.

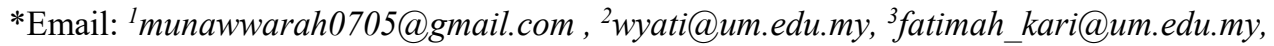 \\ nurulhuda@um.edu.my
}

\begin{abstract}
Housing has always been one of the major issues that affect peoples' quality of life, especially in the urban area. The increased number of population in urban area led to an increase in housing demand in the market. Neighbourhood satisfaction is an important factor of housing demand in urban areas. The objective of this study is to assess the relationship between housing attributes and neighbourhood satisfaction in the Klang Valley, Malaysia. Primary data collection through survey on 500 respondents was undertaken and analysed using SPSS and Structural Equation Modelling. The findings revealed that there is positive and significant relationship between housing attributes and neighbourhood satisfaction. The implication of this study found that housing attributes are noteworthy determinants in assessing the significance of neighbourhood satisfaction. The result of this study would assist policy making in proposing actual improvement in sustainable development in neighbourhood area and enhance on the improvement on the housing attributes that focus on providing more affordable housing and housing choice in the Klang Valley.
\end{abstract}

Keywords: Housing Attributes, Neighbourhood, Satisfaction

\subsection{INTRODUCTION}

Housing is intrinsically valuable to people as a house not only provides shelter from extreme weather conditions and a place to sleep and rest but also a home that is a centre of family life where the children are born and raised and socialisation takes place (Alber, 2004). Housing is one of the most important components of urban economy development. Maslow's Theory of Hierarchy of Needs highlighted that housing as shelter forms a more basic need compared to security, food and love. Housing can be seen as a valuable asset that has a great impact on society's wellbeing. Housing aspiration and affordability also play important roles in neighbourhood satisfaction (Loo, 1986; Burby \& Rohe, 1986). Hence, housing issues are very important especially in urban areas that experience population increase as urbanisation occurs. However limited finances can be a problem for the resident in achieving their desires when buying a house. The housing demand would also depend on the variety of housing choice, the affordability of housing that is provided in the neighbourhood, access to facilities and services, the physical condition and safety in the housing area (Morris et al., 1976; Rent, 1978; Ukoha \& Beamish, 1997). 
The studies on housing have gone beyond the study of physical and social features. Recent ones have focused on how people assess their housing characteristics and how they affect their neighbourhood satisfaction. Neighbourhood satisfaction can be defined as how the residents feel towards their residential premises as well as the emotional response given to a person's dwelling (Francescato et al., 1979). Furthermore, neighbourhood satisfaction also emanates from the evaluation of housing conditions and attributes. It is also a component of evaluation approach to assess the quality of housing unit in residential area. It is about how the households judge their housing conditions based on the actual housing situation and housing norms. The household will be highly satisfied with the neighourhood if the current housing situation meets their norms (Ibem, 2013). There are different definitions in explaining neighbourhood satisfaction. Some of the researchers used 'residential satisfaction' to explain the satisfaction of the neighbourhood. Residential neighbourhood satisfaction can be defined as the feeling of contentment when one has or achieves what one needs or desires in a house (Galster, 1987; Mohit, 1987). In another definition by Onibokun (1974), residential satisfaction can be defined as satisfaction with dwelling unit and satisfaction with the neighbourhood area.

Rashid et al. (2013) in their study proved that housing attributes are important in determining neighbourhood choice that can affect neighbourhood satisfaction. The study focuses on the environment of the housing and neighbourhood area. Safety, provision of facilities/services and social environment were identified as housing attributes that influence neighbourhood satisfaction. In another study by Gan et al. (2016) that studied on the migrant workers' satisfaction on public rental housing in China, it was revealed in the study that housing quality, supporting facilities, and estate management service was strongly associated with the residential satisfaction. A different housing study by Mohamad (2016) found that young people who live in urban area such as the Klang Valley are currently having a major issue in owning a house due to the high house prices in the Klang Valley, which have restricted their ability to own a house. The young adult represents the age group between 20 -35 years old and most of them are active population in migration. Based on Mohamed (2016) results, over $70 \%$ of young people choose to live in urban area and the main reason they choose to stay in urban area is probably due to the proximity to their working place and availability of facilities in urban location.

Housing is at the centre of sustainable development agenda where the future of urbanisation will depend on how the cities position housing as a priority in the country development. It is expected more and more people will reside in urban areas by 2030 and this is the challenges where the housing played an important role in future cities development and everyone can enjoy their life within their neighbourhood area. Thus, housing attributes do not only represent shelter and basic needs but also relate to how people evaluate their living satisfaction in their neighbourhood area. In line with these housing issues and scenario, this study aims to assess the housing attributes that can affect neighbourhood satisfaction in Klang Valley. Continuous assessment on neighbourhood satisfaction is needed as it is used for future cities planning and also will contribute to future housing policy especially in addressing housing affordability issue in Klang Valley.

\subsection{LITERATURE REVIEW}

\subsection{Definition of Housing Attributes}

Research on housing has received attention not only about its physical, structural and functional aspects but also how people think of their housing environment and how it affects their lives. Measuring the housing quality using satisfaction surveys have become an important and regular activity in order to ensure people are satisfied with their housing and also with the services provided 
in their neighbourhood (Hayward, 1977; Lawrence, 1987; Varady \& Carrozza, 2000, p. 799; Mohit, 2010). The Maslow's Theory Hierarchy of Needs highlighted that housing forms most important needs compared to security, foods and love. Housing is a valuable asset that has a great impact on society's wellbeing. Housing aspiration and affordability also play an important role in neighbourhood satisfaction (Loo, 1986; Burby \& Rohe, 1989).

Economic literature draws special attention to the concept of housing but there is no specific definition of housing. There are different concepts of housing by different researchers. Housing was defined by Smith (1963) as a commodity, Ricardo (1817) defines housing as tangible asset with potential return and Marshal (1890) defines housing as capital that similar to machine, if it operated by worker, but as a commodity if it is not operated. Henilane (2015) in his study stated that the concept of housing has changed according to changes in politics, economics and other areas. Housing can be defined as dwellings provided for people and housing also can be defined as building or building structure complying with requirements of laws and regulations and where the individuals with their families may live. Housing also can be described as specific and relatively limited, physically, biologically socially close place where people and groups of people can live their biosocial life by receiving services, performing house chores and other biosocial activity. Housing nowadays focuses more on satisfaction and cost of the housing. The satisfaction that has been highlighted include comfort of the housing, convenient and appropriate, but at the same time also has included energy-efficient, the affordability of buying the housing as well as the construction and maintenance that should be proportionate to the satisfaction that can be obtained from the housing (Melnikas, 1998).

Attributes can be defined as "a quality proper to a characteristic of a person or thing" (Zinas \& Jusan, 2010, p.24.) and can be defined as features or aspects of products or services (ValetteFlorence and Rapacchi, 1991). Botschen et al. (1999) defined attributes as characteristics of product or services or behaviour that are preferred or sought for by consumers. Attributes also considered as relatively concrete meaning that represents physical or perceptible characteristics in a product (Gengler et al., 1999). Valette-Florence and Rapacchi (1991) view attributes as features or aspects of products or services. While agreeing to all these definitive views, attributes can be seen as the intrinsic and physical features, properties or characteristics that define a product or person.

Olson \& Reynolds (1983) has divided attributes into two levels i.e. concrete attributes and abstract attributes. Abstract attributes are defined as the directly perceptible physical characteristics of a product, e.g. price, colour, and weight (Vriens \& Hofstede, 2000), relatively intangible characteristics, such as style and brand (Lin, 2002), or perceived value or importance (Botschen et al., 1999). Mahmud (2007) further classifies concrete attributes into two groups, namely, element and relationship, when it relates to housing. He sees abstract attributes as "meanings" perceived by the housing consumer.

From the definitions of housing and attributes from the past literature, housing attributes can be defined as housing features that can satisfy the residents in the neighbourhood area. Many researches have shown that housing attributes are divided into intrinsic housing attributes and extrinsic attributes. Intrinsic attributes are interior living space (Cupchik, Ritterfeld, \& Levin, 2003) and extrinsic attributes are exterior design and exterior space (Bhatti \& Church, 2004) to neighbourhood and locational indicators such as environmental qualities. Housing features are divided into two types known as dwelling and environmental features (Boumeester, 2011). Housing attributes are integral to shaping perception about housing quality which is correlated with feelings about neighbourhoods. The inhabitant's quality of life is determined by the state of his housing and 
good quality housing attributes can play an important role in improving public health and strengthening social cohesion (Kahlmeier et al., 2001; Aliu \& Adebayo, 2010).

\subsection{Relationship of housing attributes and neighbourhood satisfaction.}

Generally, housing satisfaction research used subjective measurement to demonstrate a correlation between housing attributes and neighbourhood satisfaction. Housing is central to the everyday life of human beings and plays an important role in providing people satisfaction. The study by Lee and Guest (1983) found there is a significant relationship between housing dissatisfaction and neighbourhood dissatisfaction. Karim (2008) findings stated that respondents with good community and facilities in their housing area are more satisfied with their neighbourhood. This study was also supported by Mohit (2010) findings which showed that residents moderately satisfied with dwelling unit support services, followed by public and neighbourhood facilities than dwelling unit features and social environment, which have higher percentage of respondents with low level of neighbourhood satisfaction.

Neighbourhood satisfaction is an outcome which is of interest to planners, and policymakers. Neighbourhood is known to be as the place within an area with physical boundaries where people identify their homes and where they live out and organise their private life (Rahman et al., 2012). Neighbourhood satisfaction is also conceptualised by the residential environments consisting the housing unit, the neighbourhood and the community in which they are located. This can be concluded that the housing environments are representing with the dwelling unit being contained within the neighbourhood and community. The geographical location is also part of the important aspect in explaining the quality of the dwelling unit (Campbell, Converse, \& Rodgers, 1976; Varady \& Carroza, 2000)

There has been an increased emphasis on the sustainability of urban development by capitalist societies. To have a great quality of life, neighbourhood satisfaction must be of concern. (Howley et al., 2009; Mohan and Twigg, 2007; Sirgy and Cornwell, 2002). Lu (1999) stated that household makes their judgements about residential conditions based on their needs and expectation. The absence of complaints by the residents with high degree of congruence between actual and desired situations is called satisfaction. The dissatisfaction can occur when there is incongruence between their actual housing and neighbourhood. The study concluded that housing attributes are one of the major factors leading to neighbourhood satisfaction. Howley et al. (2009) evaluated the relationship between high-density living and neighbourhood satisfaction within the central city. The findings from the research showed environmental quality, noise, lack of community involvement, traffic and lack of services and facilities are the factors that influence the dissatisfaction to the neighbourhood. Neighbourhood satisfaction is influenced by dwelling satisfaction. The results from the study indicated that residents who are satisfied with facilities provided such as shop and green spaces are more satisfied with the neighbourhood in general (Prementier et al., 2010; Lu, 1999; Mohan and Twigg, 2007).

Measuring the neighbourhood satisfaction are based on the noise, low crime rate, cleanliness, accidents, social environment, security and community relations in the neighbourhood area. Results of previous studies in Sungai Bonus public low-cost housing have shown that social environment has a higher percentage of respondents with a low level of satisfaction (Mohit, 2010; Aiello, 2010). It is supported by the findings of Sedaghatnia (2013) study in which the respondents comprising the residents in centre of Kuala Lumpur gave lowest satisfaction to safety. Community interaction in housing area and neighbourhood, demographic background and place attachment are the social 
factors that have been identified in the study by Rahman et al. (2012). Crime and distance to the city centre have no significant effect on the satisfaction (Permentier \& van Ham, 2011). Leslie \& Cerin (2008) found different results on how the level of crime is correlated with neighbourhood satisfaction. Temelová \& Slezáková (2014) studied the level of satisfaction of elderly about public green space and safety and it was found that there is positive relationship between public green space and safety with neighbourhood satisfaction. In addition, Salleh (2008) findings showed that neighbourhood facilities showed a significant impact on low cost housing satisfaction.

Building features such as the number of bedrooms, size and location of kitchen and quality of housing units are some of the housing attributes that have been discussed by most of the researches and they were found to be strongly related to residential satisfaction (Arifin et al., 2010; Mohit, 2015). In Malaysia, the study by Oh (2000) on housing satisfaction of middle-income households revealed that the residents were satisfied with space and house price but they are not satisfied with the size of kitchen, plumbing and public facilities provided in their housing area. Mohit (2015), in his study assessing residents' satisfaction for double storey houses using multiple regression analysis indicate that improvement of two housing design element i.e. study room and family hall, as well as five neigbourhood elements which include food stalls, neighbourhood relations, garbage collection, pedestrian walkways and crime protection, can significantly affect resident's overall housing satisfaction. Pruitt (1977) in his study found that tenure, age of dwelling and structural quality affected housing satisfaction. The study found that there is negative relationship between age of dwelling and housing satisfaction. A study on the assessment of residential satisfaction on public housing by Etminani-Ghasrodashti (2017) revealed that built environment variables such as buildings' physical features were the main factors that contribute overall residents' satisfaction, but social features found had little impact on resident's satisfaction.

Neighbourhood quality assessment is also affected by personal characteristics such as age, race and ethnicity, length of residence, and socioeconomic status. Older people with long term residents of their homes found have high neighbourhood satisfaction compared to younger people (Greenberg and Crossney, 2007). Housing affordability is one of the problems facing by young people (Abd Aziz et al., 2014 \& Henman and Jones, 2012). Housing affordability is found to have significant relationship to the neighbourhood satisfaction where the neighbourhood satisfaction is lower among the poor income population as they have to pay high cost on housing (Quigley and Raphael, 2004).

Upon this scenario, housing choice is also important in determining neighbourhood satisfaction due to the housing affordable issues. Housing choice plays an important role in structuring the cities and positively affect satisfaction of the people's in the neighbourhood. People will make sure they have a good choice in choosing their neighbourhood area and types of housing as housing is difficult and costly to demolish or modify. People will decide first and considering the neighbourhood area which they will stay in future, which the consideration is based on their housing choice and preferences. If types of housing on offer in particular neighbourhood area are not suitable based on their preferences, they will simply choose somewhere else to live that suit their preferences (Kelly, 2011). Housing choice allowing the individual or household to decide on their choice of house either they prefer to own or rent, types of house, choice of location and the tenure choice that can affect the housing affordability to the younger household (Zyed et al., 2016).

Most of the previous studies discussed more on the physical aspects, social, environment and building features in examining housing satisfaction and neighbourhood satisfaction (Arifin et al., 2010; Mohit, 2015; Etminani-Ghasrodashti, 2017; Permentier \& van Ham, 2011). However, as argued by Mohit (2015), there are various housing and neighbourhood attributes affecting the level of 
neighbourhood satisfaction that can vary by housing types, tenure, countries and culture that required further studies. This study is different from other studies as this study includes intangible attributes including affordability, housing choice, cleanliness, safety and low crime rates and accessibility to public facilities in their neighbourhood which are considered as housing attributes. The lack of literature on how housing affordability and housing choices that are considered as housing attributes can affect neighbourhood satisfaction has led to the following hypothesis:

H1: Housing attributes have significant and direct effect on Neighbourhood satisfaction.

\subsection{METHODS}

\subsection{Research Design}

The main purpose of this study is to assess the relationship of housing attributes and neighbourhood satisfaction. Based on the literature, neighbourhood satisfaction can be obtained from the satisfaction of housing attributes. To obtain the results of satisfaction factors, a formulation of the questionnaire was used as a primary source. Structured questionnaire used in preparing the questionnaire for the survey. The questionnaire design was direct, simple and familiar to the respondents. Respondents satisfaction level of housing and neighbourhood attributes was measured with five-point Likert scale with ' $1=$ very poor...5=very good.

\subsection{Data Collection and Analysis}

This study covers seven local authority areas in the Klang Valley namely Kuala Lumpur City Hall, Petaling Jaya City Council, Shah Alam City Council, Klang Municipal Council, Sepang Municipal Council, Subang Jaya Municipal Council and Selayang Municipal Council. The main reason in choosing these seven local authorities was because they represent the Greater Klang Valley (Zyed et al., 2016). A sample of 500 households was selected by stratified random sampling. The stratification criteria were (1) The respondents must reside in middle income-medium cost housing and (2) Respondents must be household within the age of 21 and above.

In order to ensure the reliability of questions, a pilot survey of ten questionnaires was administered in two study areas, which resulted in improving the questions to be more direct, simple and easy to understand to avoid difficulty in answering the questions. The field survey was conducted in October and November 2017. The face-to-face surveys were conducted during weekends for a better response from residents. Respondents took between 20 and 30 minutes to fill in the survey. Data were analysed using SPSS to generate frequencies and percentage of respondent demographic characteristics and mean scores of satisfactions. Structural Equation Modeling used to analyse the relationship between housing attributes and neighbourhood satisfaction.

\subsection{RESULTS AND DISCUSSION}

\subsection{Socio-Demographic Characteristics}

The socio-demographic characteristics were analysed using frequency distribution (Table 1). From the analysis, gender groups are fairly represented with male $55 \%$ and female $45 \%$. The age groups of the respondents are between 21 years old to 59 years old where $58.9 \%$ of the respondents are married. Education of the respondents are $16.2 \%$ for postgraduates and $47.4 \%$ are undergraduate. In terms of employment sectors, the majority of the respondents are from private sector $(60.1 \%)$ and where $28.8 \%$ of the respondents are working in public sector. With respect to the monthly income 
level, the most frequent group is between RM1000 - RM3000 (53.8\%) and monthly income per month from RM9001 and above are the smallest groups (5.9\%). The majority of the respondents worked in private sector $(60.1 \%)$. This group income is from individual income of the respondents and it can be concluded that majority of the respondents are from lower and middle income group that can help to give their individual assessment on their satisfaction that related to housing and neighbourhood satisfaction.

Table 1: Socio-Demographic Analysis

\begin{tabular}{|l|l|}
\hline Demographic & Percentage \\
\hline Gender & \\
Male & 55 \\
Female & 45 \\
Age & \\
21-30 & 47.2 \\
$31-45$ & 36.6 \\
46-59 & 16.2 \\
Education Level & \\
No formal education & 1.2 \\
Primary School & 2.5 \\
PMR/SRP & 0.8 \\
SPM/SPMV & 10.6 \\
STPM/STAM/Matriculation & 3.9 \\
Certificate & 2.0 \\
Diploma & 15.1 \\
Degree & 47.4 \\
Tertiary education (Master/PhD) & 16.2 \\
Others & 0.2 \\
Marital Status & \\
Single & 39.9 \\
Married & 58.9 \\
Divorced & 1.2 \\
Employment Sector & \\
Private Sector & 60.1 \\
Public Sector & 28.8 \\
Self Employed & 7.5 \\
Others & 3.5 \\
Monthly Net Income (RM) & \\
1000-3000 & 53.8 \\
3001-5000 & 31.9 \\
5001-9000 & 8.4 \\
\hline
\end{tabular}

From the result, the young household contributes to the larger percentage of the total population and most of the respondents are from middle income. The term 'young' has been introduced by the Malaysian Youth Council to be the age range of 15 to 40 years old (Sohaimi et al., 2017). The 
respondents were well educated as majority of the respondents had secondary and tertiary education. This is important for this study as they will be more responsible for their preferences and satisfaction towards their housing and neighbourhood.

\subsection{Satisfaction with Housing Attributes}

The analysis showed that the mean scores of satisfaction with housing attribute are between 3.14 to 3.52 (refer to Table 2). The highest mean score is given to' the physical condition of the house meets their needs (3.52)' and the lowest score is given to 'housing in neighbourhood area is relatively affordable (3.14)'. The mean scores show that the score is positive between 3.14 to 3.52 .

This suggests that there is limited housing choice such as housing types that affordable for young household in the housing market. As most of the respondents are from young household and middle income, they are looking for more affordable housing that fits their income. The location of their housing nearby to the various public facilities and service also found to be an important factor to the residents. If they are near to public facilities and services such public transportation; they can reduce the cost of travelling to their workplace that could be far away from the housing location. The government and urban planner have to come out with new planning that to focus on providing more varieties of affordable housing choices especially for the middle income in the Klang Valley.

Table 2: Satisfaction with Housing Attributes

\begin{tabular}{|l|l|l|c|}
\hline Features & $\begin{array}{l}\text { Item } \\
\text { Code }\end{array}$ & Item & Mean \\
\hline $\begin{array}{l}\text { Housing } \\
\text { Attributes }\end{array}$ & 7Di & $\begin{array}{l}\text { Various choices of housing (from high end to low cost } \\
\text { housing). }\end{array}$ & 3.36 \\
\cline { 2 - 4 } & 7Dii & Housing in my neighbourhood area is relatively affordable. & 3.14 \\
\cline { 2 - 4 } & 7Diii & $\begin{array}{l}\text { The location of my house nearby various public facilities and } \\
\text { services }\end{array}$ & 3.46 \\
\cline { 2 - 4 } & 7Div & The physical condition of the house meets your need & 3.52 \\
\cline { 2 - 4 } & 7Dv & Safety and security is good in my neighborhood area & 3.38 \\
\hline
\end{tabular}

\subsection{Satisfaction with Neighbourhood Attributes}

The analysis in Table 3 shows that the mean score of satisfaction with neighbourhood attributes to be between 2.89 to 3.73 . The attribute with the highest score mean is 'Location of my neighbourhood is strategic and easy access from other areas' (3.73) while the lowest score is given to 'My neighbourhood adopted green technology for a sustainable lifestyle' with a mean score of 2.89.

Compared to other attributes on the neighbourhood measurement, it can be concluded that the strategic location of the neighbourhood is important as it is to make sure it is easy to access from other places. Strategic location is important to the residents as easy access and proximity to the various activities such as shops, shopping mall, school, workplace, public transport and public amenities and recreation place are important attributes. Most of the study areas provided with various 
types of leisure place such as recreational parks and shopping malls. The results also showed that the neighbourhood's adoption of green technology was found least satisfied by the residents. The communities are aware of green technology. It is because green technology or known green infrastructure can help to make the world more sustainable for future (Tan,2016).

Table 3: Satisfaction with Neighbourhood Attributes

\begin{tabular}{|l|l|l|l|}
\hline Features & $\begin{array}{l}\text { Item } \\
\text { Code }\end{array}$ & Item & Mean \\
\hline $\begin{array}{l}\text { Neighbourhood } \\
\text { Attributes }\end{array}$ & E1a & $\begin{array}{l}\text { My neighbourhood has good provisions of } \\
\text { facilities and services that meet my needs. }\end{array}$ & 3.58 \\
\cline { 2 - 4 } & E1b & $\begin{array}{l}\text { My neighbourhood is clean and well- } \\
\text { maintained. }\end{array}$ & 3.50 \\
\cline { 2 - 5 } & E1c & $\begin{array}{l}\text { Trust and confidence among each other (with } \\
\text { other community) }\end{array}$ & 3.58 \\
\cline { 2 - 5 } & E1d & $\begin{array}{l}\text { My neighbourhood is safe and have low } \\
\text { crime rate. }\end{array}$ & 3.44 \\
\cline { 2 - 5 } & E1e & $\begin{array}{l}\text { My neighbourhood has beautiful landscape } \\
\text { and green area. }\end{array}$ & 3.29 \\
\cline { 2 - 5 } E1f & $\begin{array}{l}\text { The location of my neighbourhood is } \\
\text { strategic and easy access from other area. }\end{array}$ & 3.73 \\
\cline { 2 - 5 } & E1g & $\begin{array}{l}\text { My neighbourhood adopted green technology } \\
\text { for a sustainable lifestyle }\end{array}$ & 2.89 \\
\cline { 2 - 5 } & E1h & Good place to raise kids & 3.58 \\
\cline { 2 - 5 } & E1i & $\begin{array}{l}\text { Overall, I am satisfied with my } \\
\text { neighbourhood }\end{array}$ & \\
\hline
\end{tabular}

\subsection{Confirmatory Factor Analysis (CFA)}

The Confirmatory Factor Analysis is required to validate the measurement model of all latent constructs involved in the study before modelling the relationship between the variables of housing attributes and neighbourhood satisfaction using Structural Equation Modeling (SEM). Fitness Indexes used in SEM are to test how fit is the model to the data at hand. There are three model fit categories namely Absolute Fit Index, Incremental Fit and Parsimonious Fit Index. Meanwhile, the reliability of the constructs will be assessed through the Composite Reliability and Average Variance Extracted (Awang, 2015). The recommended value for each fitness index (Hair, Babin, \& Krey, 2017) is presented as follows:

Table 4: Three Categories of Model Fit and level of Acceptance

\begin{tabular}{|l|l|l|}
\hline Name of category & Name of index & Level of acceptance \\
\hline \multirow{2}{*}{ Absolute Fit Index } & RMSEA & RMSEA $<0.08$ \\
\cline { 2 - 3 } & GFI & GFI $>0.90$ \\
\hline \multirow{2}{*}{ Incremental Fit Index } & AGFI & AGFI $>0.90$ \\
\cline { 2 - 3 } & CFI & CFI $>0.90$ \\
\hline
\end{tabular}




\begin{tabular}{|l|l|l|}
\hline \multirow{2}{*}{ Parsimonious Fit Index } & TLI & TLI $>0.90$ \\
\cline { 2 - 3 } & NFI & NFI $>0.90$ \\
\hline Chisq/df & Chi-Square $/ \mathrm{df}<3.0$ \\
\hline
\end{tabular}

Table 5: The summary of Fitness Indexes (Housing attributes)

\begin{tabular}{|l|l|l|l|}
\hline Name of category & Name of index & Index value & Comments \\
\hline Absolute fit & RMSEA & 0.058 & The required level is achieved \\
\hline Incremental fit & CFI & 0.994 & The required level is achieved \\
\hline & TLI & 0.988 & The required level is achieved \\
\hline & IFI & 0.994 & The required level is achieved \\
\hline Parsimonious fit & Chisq/df & 2.664 & The required level is achieved \\
\hline
\end{tabular}

Table 6: The summary of Fitness Indexes (Neighbourhood Satisfaction)

\begin{tabular}{|l|l|l|l|}
\hline Name of category & Name of index & Index value & Comments \\
\hline Absolute fit & RMSEA & 0.057 & The required level is achieved \\
\hline Incremental fit & CFI & 0.986 & The required level is achieved \\
\hline & TLI & 0.981 & The required level is achieved \\
\hline & IFI & 0.986 & The required level is achieved \\
\hline Parsimonious fit & Chisq/df & 2.602 & The required level is achieved \\
\hline
\end{tabular}

Table 5 and Table 6 show that all the fitness indexes are achieved at the required level. It can be concluded that all the measurement model of the housing attributes and neighbourhood attributes achieved the construct validity.

The study needs to report the Composite Reliability (CR) which indicate the reliability of the construct and the Average Variance Extracted (AVE) which indicate the convergent validity of the construct. The threshold value for CR is 0.6 or higher while the threshold value of AVE has to be 0.5 or higher.

Table 7: Composite Reliability and Average Variance Extracted

\begin{tabular}{|l|l|l|}
\hline & CR & AVE \\
\hline Neighbour & & \\
Satisfaction & 0.919 & 0.669 \\
Housing & 0.882 & 0.652 \\
Attributes & & \\
\hline
\end{tabular}

The results in table 7 show all Composite Reliability (CR) and Average Variance Extracted (AVE) exceeds the threshold value of 0.6 and 0.5 respectively which indicate the convergent validity and composite reliability of all main constructs in the model (Zainudin, 2015). 


\subsection{Structural Equation Model (SEM)}

Once the validity and reliability of the measurement were achieved, Structural Equation Modelling (SEM) is used to analyse the proposed hypothesis. SEM was used to assess the relationship between the variables which is Housing attributes and Neighbourhood satisfaction.

Table 8: Level of significant for Regression Weight.

\begin{tabular}{|lll|llll|}
\hline & & Estimate & S.E. & C.R. & P \\
\hline Neighborhood_Satisfaction & --- & Housing_Attributes & .277 & .063 & 4.415 & $* * *$ \\
\hline
\end{tabular}

Table 8 shows the results of hypothesis testing for the causal effect of Housing attributes on Neighbourhood Satisfaction as expressed in H1. The path coefficient of Housing on Neighbourhood Satisfaction is 0.277 . This value indicates that for every one unit increase in Housing attribute, its effect would contribute 0.277 unit increase in Neighbour Satisfaction. The regression weight estimate of 0.277 has a standard error of 0.063 . The critical ratio is shown as 4.415 standard errors above zero. The probability of getting a critical ratio of 4.415 in absolute value is $0.000(\mathrm{P}=* * * *)$. The result shows that the regression weight for Housing attribute in the prediction of Neighbourhood Satisfaction is significant at 0.000 level, hence, the hypothesis proposed in H1 showed that Housing attributes has a positive and significant effect on Neighbourhood Satisfaction and is duly supported.

\subsection{CONCLUSION}

Housing attributes can be seen as an important component of neighbourhood satisfaction. This paper aims to assess the relationship between housing attributes and neighbourhood satisfaction among urban residents in the Klang Valley The result from the study indicated that, generally the residents are moderately satisfied with housing attributes and neighbourhood attributes. The results also showed that the neighbourhood areas need more affordable housing with more housing choice especially for the young people in the Klang Valley. From the results also can be concluded that neighbourhood satisfaction is highly related to the location of housing that that has close proximity to various public facilities and services.

This study provides new insights on how satisfaction on housing attributes can influence the neighbourhood satisfaction. The result reflects the previous studies by Sirgy (2002), Mohit (2012) and Salleh et al. (2012) that focused on social, physical and economic features in measuring the neighbourhood satisfaction which can then affect on urban quality of life. This study proposed housing attributes in assessing the relationship between housing attributes and neighbourhood satisfaction. The result from the finding showed that there is positive and significant relationship between housing attributes and neighbourhood satisfaction.

\subsection{REFERENCE}

1. Abdul Rahman, N., Omar, D., \& Salleh, A. G. (2012). Determinant factors of neighbourhood quality. Planning Malaysia, 10, 1-16.

2. Abd Aziz, D. W., Hanif, N. R., \& Singaravello, K. (2011). A Study of Affordable Housing within the Middle Income Households in the Major Cities and Towns of Malaysia. Australian Journal of Basic and Applied Sciences, 5(8), 258-267. 
3. Aliu, I. R., \& Adebayo, A. (2010). EVALUATING THE INFLUENCE OF HOUSING QUALITY ON URBAN RESIDENTS'WELLBEING: THE CASE OF LAGOS NIGERIA. International Journal of Academic Research, 2(6).

4. Aiello, A., Ardone, R. G., \& Scopelliti, M. (2010). Neighbourhood planning improvement: Physical attributes, cognitive and affective evaluation and activities in two neighbourhoods in Rome. Evaluation and Program Planning, 33(3), 264-275.

5. Alison, P. et al. (2002) What makes people dissatisfied with their neighbourhoods? Urban Studies. 39(13): 2111-2124.

6. Alber, J. (2004). Health and care in an enlarged Europe. European foundation for the improvement of living and working conditions.

7. Aulia, D. N., \& Ismail, A. M. (2013). Residential satisfaction of middle income population: Medan city. Procedia-Social and Behavioral Sciences, 105, 674-683.

8. Baqutayan, S. M. (2015). The Impact of Housing Issue on the Well-being of Middle-Income Group. Mediterranean Journal of Social Sciences, 6(6S1), 522.

9. Botschen, G., Thelen, E. M., \& Pieters, R. (1999). Using Means-End Structures for Benefit Segmentation and Application to Services. European Journal of Marketing, 33(1-2), 38-58.

10. Boumeester, H. J. (2011). Traditional housing demand research. In The measurement and analysis of housing preference and choice (pp. 27-55). Springer, Dordrecht.

11. Bhatti, M., \& Church, A. (2004). Home, the culture of nature and meanings of gardens in late modernity. Housing studies, 19(1), 37-51.

12. Burby, R. J., \& Rohe, W. M. (1989). Deconcentration of public housing: Effects on residents' satisfaction with their living environments and their fear of crime. Urban Affairs Quarterly, 25(1), 117-141.

13. B Mohamad, M. H., b Nawawi, A. H., \& b Sipan, I. (2016). Review of building, locational, neighbourhood qualities affecting house prices in Malaysia. Procedia-Social and Behavioral Sciences, 234, 452-460.

14. Cupchik, G. C., Ritterfeld, U., \& Levin, J. (2003). Incidental learning of features from interior living spaces. Journal of Environmental Psychology, 23(2), 189-197.

15. Campbell, A., Converse, P. E., \& Rodgers, W. L. (1976). The quality of American life: Perceptions, evaluations, and satisfactions. Russell Sage Foundation.

16. Etminani-Ghasrodashti, R., Majedi, H., \& Paydar, M. (2017). Assessment of Residential Satisfaction in Mehr Housing Scheme: A Case Study of Sadra New Town, Iran. Housing, Theory and Society, 34(3), 323-342.

17. Fuentes, N., \& Rojas, M. (2001). Economic theory and subjective well-being: Mexico. Social Indicators Research, 53(3), 289-314.

18. Galster, G. C. (1985). Evaluating indicators for housing policy: Residential satisfaction vs marginal improvement priorities. Social Indicators Research, 16(4), 415-448. 
e-issn: 2229-8568

19. Galster, G.C. (1987) Identifying the correlates of dwelling satisfaction: An empirical critique. Environment and Behaviour. 19(5): 539-568.

20. Gengler, C. E., Mulvey, M. S., \& Oglethorpe, J. E. (1999). A Means-End Analysis of Mother's Infant Feeding Choices. Journal of Public Policy and Marketing, 18(2),172-188

21. Greenberg, Michael, and Kristen Crossney. 2007. Perceived neighborhood quality in the United States: Measuring outdoor, housing and jurisdictional influences. SocioEconomic Planning Sciences 41: 181-194. Journal Online. Available through Academic Search Premier.

22. Henman, P., \& Jones, A. (2012). Exploring the use of residual measures of housing affordability in Australia: Methodologies and concepts. AHURI Final Report, (180), i-35.

23. Howley, P., Scott, M., \& Redmond, D. (2009). Sustainability versus liveability: an investigation of neighbourhood satisfaction. Journal of environmental planning and management, 52(6), 847-864.

24. Hayward, D. G. (1977). Housing research and the concept of home. Housing Educators Journal, 4(3), 7-12.

25. Henilane, I. (2015a). The Evaluation of housing situation in Latvia. In XVI Turiba University International Conference "Towards Smart, Sustainable and Inclusive Europe: Challenges for Future Development,” (pp. 93-106). Riga, Latvia. ISSN 1691-6069

26. Karim, H. A. (2008). The satisfaction of residents on community facilities in Shah Alam, Malaysia. Asian Social Science, 4(11), 131-137.

27. Kahlmeier, S., Schindler, C., Grize, L., \& Braun-Fahrländer, C. (2001). Perceived environmental housing quality and wellbeing of movers. Journal of Epidemiology \& Community Health, 55(10), 708-715.

28. Kelly, J. F., Weidmann, B., \& Walsh, M. (2011). The housing we'd choose (p. 10). Melbourne: Grattan Institute.

29. Lawrence, R. J. (1987). Housing, dwellings and homes: Design theory, research and practice. John Wiley \& Sons.

30. Loo, C. (1986). Neighborhood satisfaction and safety: a study of low-income ethnic area. Environment and Behavior, 18(1), 109-131.

31. Lu, M. (1999). Determinants of residential satisfaction: Ordered logit vs. regression models. Growth and change, 30(2), 264-287.

32. Leslie, E., \& Cerin, E. (2008). Are perceptions of the local environment related to neighbourhood satisfaction and mental health in adults?. Preventive medicine, 47(3), 273-278.

33. Lee, B. A., \& Guest, A. M. (1983). Determinants of neighborhood satisfaction: A metropolitan-level analysis. Sociological Quarterly, 24(2), 287-303.

34. Lu, M. (1999). Do people move when they say they will? Inconsistencies in individual migration behavior. Population and environment, 20(5), 467-488.

35. Marshall, A. (1890). Principles of Economics. London: Macmillan and Co 
36. Morris, E. W., \& Winter, M. (1978). Housing, family and society. New York: Wiley.

37. Mohan, J., \& Twigg, L. (2007). Sense of place, quality of life and local socioeconomic context: evidence from the survey of English housing, 2002/03. Urban studies, 44(10), 20292045 .

38. Mohit, M. A., Ali, M. S., \& Design, E. (2016). Neighbourhood satisfaction and qoul in middle- income housing in kuala lumpur city, malaysia, XIV, 81-94.

39. Mohit, M. A., Ibrahim, M., \& Rashid, Y. R. (2010). Assessment of residential satisfaction in newly designed public low-cost housing in Kuala Lumpur, Malaysia. Habitat international, $34(1), 18-27$

40. Ogu, V. I. (2002). Urban residential satisfaction and the planning implications in a developing world context: The example of Benin City, Nigeria. International Planning Studies, 7(1), 3753.

41. Olson, J. C., \& Reynolds, T. J. (1983). Understanding consumers' cognitive structures: Implications for advertising strategy. Advertising and consumer psychology, 1, 77-90.

42. Permentier M., Bolt G. and van Ham M. (2011) Determinants of neighbourhood satisfaction and perception of neighbourhood reputation. Urban Studies 48(5), 977-996.

43. Pruitt, L. (1978). The influence of residential domain satisfaction and life domain satisfactions on overall satisfaction with quality of life. In W. Rogers \& W. Ittelson (Eds.), New Directions in Environmental Design Research: Proceedings of the 9th Annual Environmental Design Research Association Conference (pp. 226-238). Tucson, AZ: Environmental Design Research Association.

44. Quigley, J. M., \& Raphael, S. (2004). Is housing unaffordable? Why isn't it more affordable?. Journal of Economic Perspectives, 18(1), 191-214.

45. Raja Noriza Ariffin, et ,a.l (2010). Residential satisfaction in private low - cost housing in the urban area: A case study of the Klang Valley, Malaysia. International Housing Research Conference. Istanbul, Turkey, 4 -7 July 2010.

46. Rashid, S., Ngah, T., \& Eluwa, S. (2013). Neighbourhood choice factors and residents satisfaction in old and new neighbourhoods of Slemani City, Kurdistan-Iraq. Journal of Environmental and Earth Science, 3(2), 72-80.

47. Rahman, N. A., Omar, D., \& Salleh, A. G. (2012). Determinant factors of neighbourhood quality. PLANNING MALAYSIA JOURNAL, 10(3).

48. Rent, G. S. \&, Rent, C. S. (1978). Low-income housing: factors related to residential satisfaction. Environment and Behavior 10, 459-488

49. Ricardo, D. (1817). On the Principles of Political Economy and Taxation. London: John Murray, Albemarle Street

50. Rossi, P. H. (1955). Why families move? Glencoe, Illinois: The Free Press

51. Salleh, A. G. (2008). Neighbourhood factors in private low-cost housing in Malaysia. Habitat International, 32(4), 485-493. 
52. Satsangi, M., \& Kearns, A. (1992). The use and interpretation of tenant satisfaction surveys in British social housing. Environment and Planning C: Government and Policy, 10(3), 317-331.

53. Sedaghatnia, S., Lamit, H., Ghahramanpouri, A., \& Mohamad, S. B. (2013). An evaluation of residents' quality of life through neighborhood satisfaction in Malaysia. Environmental Management and Sustainable Development, 2(1), 114-125.

54. Sirgy, M. J., \& Cornwell, T. (2002). How neighborhood features affect quality of life. Social indicators research, 59(1), 79-114.

55. Smith, A., \& Stewart, D. (1963). An Inquiry into the Nature and Causes of the Wealth of Nations (Vol. 1). Homewood, Ill: Irwin.

56. Temelová, J., \& Slezáková, A. (2014). The changing environment and neighbourhood satisfaction in socialist high-rise panel housing estates: The time-comparative perceptions of elderly residents in Prague. Cities, 37, 82-91.

57. Ukoha, O. M., \& Beamish, J. O. (1997). Assessment of residents' satisfaction with public housing in Abuja, Nigeria. Habitat international, 21(4), 445-460.

58. Varady, D. P., \& Carrozza, M. A. (2000). Towards a better way to measure customer satisfaction levels in public housing: a report from Cincinnati. Housing Studies, 15(6), $797-$ 825 .

59. Valette-Florence, P., \& Rapacchi, B. (1991). Improvements in means-end chain analysis. Journal of advertising research, 31(1), 30-45.

60. Vriens, M., \& Hofstede, F. T. (2000). Linking Attribute, Benefits, and Consumer Values. marketing research, 12(3).

61. Zheng, X., Xia, Y., Hui, E. C., \& Zheng, L. (2018). Urban housing demand, permanent income and uncertainty: Microdata analysis of Hong Kong's rental market. Habitat International, 74, 9-17.

62. Zinas, B. Z., \& Jusan, M. M. (2017). Choice behaviour of housing attributes: Theory and measurement. Asian Journal of Environment-Behaviour Studies, 2(2), 23-37.

63. Zyed, Z. A. S., Aziz, W. N. A. W. A., \& Hanif, N. R. (2016). Housing affordability problems among young households. Journal of Surveying, Construction and Property, 7(1), 1-18. 